\title{
THE INDIRECT MEASUREMENT OF MEAN VENOUS OXYGEN TENSION DURING ANOXIA
}

\author{
BY BERNARD D. DAVIS \\ (From the Division of Industrial Hygiene, National Institute of Health, \\ U. S. Public Health Service, Bethesda, Maryland)
}

(Received for publication May 4, 1943)

Homeostatic mechanisms to compensate for the anoxia of high altitude are presented by several systems of the body and may be either rapid or delayed. Increased respiration and increased cardiac output, which tend to minimize the decrease of the pressure at which oxygen is delivered to the tissues, are immediate responses to oxygen want. In contrast, increased oxygen capacity of the blood is produced only after several days of acclimatization to anoxia, as in life on mountains. A third compensatory adjustment which has been suggested, but not demonstrated, involves changes in the intracellular enzymes such as to produce more efficient utilization of oxygen at lowered pressure. Of these three mechanisms, response to the acute oxygen want of aviation must rely essentially on the rapid respiratory and circulatory adjustments to diminish tissue anoxia. The single physiological datum which most sensitively reflects the extent of these adjustments is the mean venous oxygen tension $\left(\mathrm{MVpO}_{2}\right)$, which represents the average tension at which oxygen leaves the blood at the venous end of the capillaries.

The $\mathrm{MVpO}_{2}$ has been measured directly by several observers $(1,2)$ on blood obtained by puncture of the right side of the heart or catheterization of the right auricle, but these methods are hardly suitable for widespread use. Indirect measurement, by equilibration of suitable gas mixtures with pulmonary arterial blood in the alveoli, has been reported by a number of observers (3 to 9) since first used by Plesch in 1909 (3). These investigations, which were concerned with measurement of cardiac output employing the Fick principle, have been reviewed in detail in Grollman's monograph (10). The methods used have been largely discarded during the past decade.

The possibility of application to the problems of aviation medicine and the availability of a simpler method of measuring oxygen tension have led us to reconsider the technic of indirect measurement of the $\mathrm{MVPO}_{2}$. In seeking optimal conditions of equilibration and assuring the reliability of the method finally adopted, several thousand determinations of oxygen tension were made by a nearly instantaneous physical method with an accuracy of $0.5 \mathrm{~mm}$. Hg. The data presented here are only a small part of those available to show the reproducibility of the results.

\section{PART I-THE METHOD OF MEASUREMENT OF $\mathrm{MVPO}_{2}$}

\section{Procedure}

The following procedure was finally adopted. A Douglas bag with a wide-bore 3-way metal stopcock is filled with the desired gas mixture. The subject, wearing a nose-clip, draws 10 quiet breaths through a rubber mouthpiece connected by the stopcock with the open air. He then exhales completely to the air, draws a maximal inspiration from the bag, exhales completely to the air again, and draws another maximal inspiration. The mouthpiece is withdrawn and the subject exhales almost completely and closes his lips about the pinched stem of an empty rubber bladder, exhaling slightly at the time in order to prevent entrance of outside air. He then exhales completely into the bladder the remaining 200 to $400 \mathrm{cc}$. of air which can be expelled from the lungs. The above procedure is carried out as rapidly as possible, occupying no more than 5 seconds. The gas in the bladder is reinhaled and forcibly and completely exhaled at the normal respiratory rate of 3 seconds per cycle for a total of 4 rebreathings, and is immediately analyzed.

The proof of equilibration depends upon comparison of the $\mathrm{pO}_{2}$ of the rebreathed mixture with the $\mathrm{pO}_{2}$ of the mixture in the rinsed lungs before rebreathing. In all of the experiments on the author as subject, such data were obtained by alternating the above rebreathing procedure with an incomplete procedure (" $\mathrm{pO}_{2}$ before rebreathing") extending only to the initial expulsion into the bladder. In most of the later experiments with untrained subjects, however, the subject exhaled into a small glass Y-tube connected to 2 empty bladders, 1 of which was immediately clamped off before rebreathing. This improved procedure not only halved the time necessary for a given series of determinations, but increased the value of the comparison 
between rebreathed and unrebreathed mixtures, which were obtained simultaneously rather than alternately.

\section{Consideration of conditions of equilibration}

The lungs were rinsed with a gas mixture which would produce approximately the desired $\mathrm{pO}_{2}$, but which contained little or no $\mathrm{CO}_{2}$. Since the diffusion of $\mathrm{CO}_{2}$ between blood and alveoli is very rapid, the above procedure was based on the expectation that a rebreathed $\mathrm{N}_{2}-\mathrm{O}_{2}$ mixture would reach approximate equilibrium with venous $\mathrm{CO}_{2}$ and thereby permit $\mathrm{O}_{2}$ equilibration at normal $\mathrm{pH}$. This was substantiated in several experiments in which it was found that $(a)$ the gas mixtures after 4 rebreathings contained $\mathrm{CO}_{2}$ as expected at a partial pressure slightly above that of the normal alveolar air taken during the same experiment, and $(b)$ the addition of 6 per cent $\mathrm{CO}_{2}$ to the rinsing mixture produced no alteration in the value of $\mathrm{pO}_{2}$ attained at equilibrium. These 2 observations justified the omission of $\mathrm{CO}_{2}$ from the gas mixtures, so that the mixtures could be made up by simply partly filling Douglas bags with $\mathrm{N}_{2}$ and then exhaling into the bag until the mixture was shown by rapid analysis to have attained the desired $\mathrm{pO}_{2}$.

Most of the previously published methods involved rinsing the lungs with an appropriate mixture and then either holding the breath or rebreathing a rather large volume of gas. The results of our early experiments, however, showed that neither of these methods produced as close an approach to equilibrium as did rebreathing a small volume (200 to $400 \mathrm{cc}$.) of gas. It is obvious on theoretical grounds that equilibrium across the alveolar membrane will be more complete the smaller the sample, but a lower limit is imposed by the requirement that the sample reinspired from the bag be large enough to permit mixing of alveolar and dead space air. Evidence for the inadequacy of equilibration by holding the breath is presented below (Table I).

Uniform results were obtained only when a procedure was adopted for insuring a reasonably uniform physiological state. All the experiments were performed in the sitting position, within easy reach of all the apparatus, in order to minimize muscular activity between rebreathings. To allow for recovery from such slight exertion as was necessary, the routine was adopted of preceding each test by 10 quiet breaths through the mouthpiece. (The "basal" state was not practicable because the long intervals necessary to attain this state between tests would have severely restricted the number of analyses.) Although this procedure eliminated most of the scattering of the data, the values reflected the effect of the vigorous act of rebreathing and subsequent hyperpnea on the physiological state at the time of a repeat test a few minutes later. Thus successive tests with a low oxygen mixture caused a drop of 2 to 3 in $\mathrm{MVpO}_{2}$, and of $10 \mathrm{~mm}$. in alveolar $\mathrm{pO}_{2}$. Reproducible results were attained if a steady state was produced by spacing tests 2 to 5 minutes apart.

Since no obvious change was observed following a meal, experiments were not limited to the post-absorptive state. A much more important variable, difficult to control, was nervous tension. A higher $\mathrm{MVpO}_{2}$ appeared to be associated with a state of slight excitement or tension, as might be expected from the effect of sympathicoadrenal activity on cardiac output.

\section{Evidence of equilibrium}

In Table $I$ is presented a representative series of 63 consecutive tests on the author as subject, with different rinsing mixtures at atmospheric pressure, spaced at approximately 3-minute intervals. It is apparent that rebreathing 2 times caused less complete adjustment toward the venous $\mathrm{pO}_{2}$ than rebreathing 4 times, as would be expected; holding the breath was even less efficient than 2 rebreathings. Rebreathing 6 times caused a definite further drop when the mixture was too high, but little or none in the neighborhood of equilibrium. Thus of the 4 such tests with the 26,20 , and $14 \mathrm{~mm}$. rinsing mixtures, 2 caused a rise and 2 a fall by a fraction of a millimeter compared with the preceding 4-breath (routine) test. This is considered adequate evidence of the absence of significant recirculation.

Table $\mathrm{I}$ indicates a $\mathrm{MVpO}_{2}$ on that occasion of $29 \mathrm{~mm}$. $\mathrm{Hg}$. It appears from the data obtained with mixtures producing higher or lower initial $\mathrm{pO}_{2}$ than $29 \mathrm{~mm}$. that the process of rebreathing 4 times causes the mixture to arrive at a $\mathrm{pO}_{2}$ approximately half-way from its initial 
value to the true venous $\mathrm{pO}_{2}$. Thus the 34 $\mathrm{mm}$. mixture produced a $\mathrm{pO}_{2}$ before rebreathing of 38.8 and $\mathrm{aO}_{2}$ after 4 rebreathings of 34.0 $\mathrm{mm} . \mathrm{Hg}$.

\section{Application to previously untrained subjects}

In order to test the applicability of the method to a variety of subjects, it was taught to 14 sailors, furnished through the cooperation of the U. S. Naval Medical Center, Bethesda, Maryland. These men varied widely in intelligence, physical development, and vital capacity; no

TABLE I

Consecutive values at approximately 3-minute intervals of alveolar $\mathrm{pO}_{2}(\mathrm{~mm} . \mathrm{Hg})$ after rinsing the lungs twice with mixtures of various $\mathrm{O}_{2}$ tensions

\begin{tabular}{c|c|c|c}
\hline $\begin{array}{c}\mathrm{pO}_{2} \\
\text { before } \\
\text { rebreathing }\end{array}$ & $\begin{array}{c}\mathrm{pO}_{2} \\
\text { after 2 } \\
\text { rebreathings }\end{array}$ & $\begin{array}{c}\mathrm{pO}_{2} \\
\text { atter 4 } \\
\text { rebreathings }\end{array}$ & $\begin{array}{c}\mathrm{pO}_{2} \\
\text { after 6 } \\
\text { rebreathings }\end{array}$ \\
\hline
\end{tabular}

Rinsing mixture $\mathrm{pO}_{2}=40 \mathrm{~mm}$.

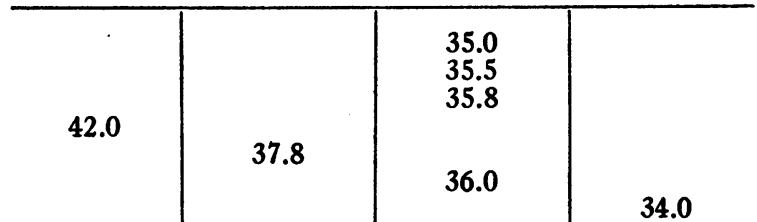

Holding breath 10 seconds without rebreathing $=38.2$

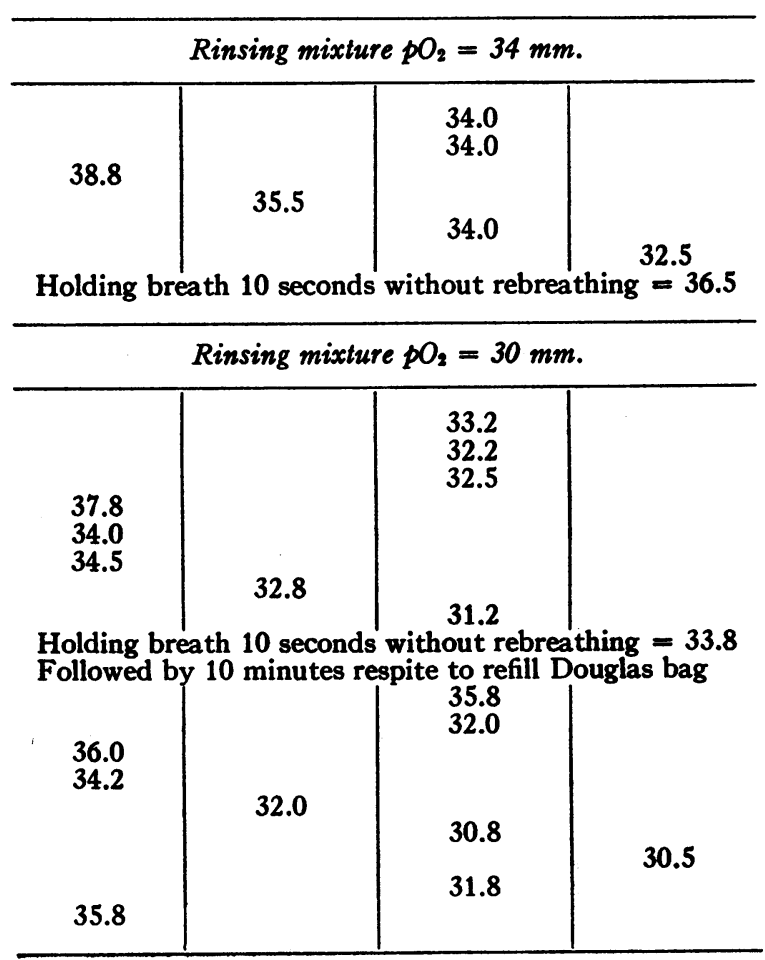

TABLE I-Continued

\begin{tabular}{c|c|c|c}
$\begin{array}{c}\mathrm{pO}_{2} \\
\text { before } \\
\text { rebreathing }\end{array}$ & $\begin{array}{c}\mathrm{pO}_{2} \\
\text { after 2 } \\
\text { rebreathings }\end{array}$ & $\begin{array}{c}\mathrm{pO}_{2} \\
\text { after 4 } \\
\text { rebreathings }\end{array}$ & $\begin{array}{c}\mathrm{pO}_{2} \\
\text { after 6 } 6 \\
\text { rebreathings }\end{array}$ \\
\hline
\end{tabular}

Rinsing mixture $\mathrm{pO}_{2}=26 \mathrm{~mm}$.

\begin{tabular}{l|l|l|l}
\hline & & 30.5 & \\
32.2 & & 30.5 & \\
& 31.8 & & \\
& & 29.0 & 29.2
\end{tabular}

Holding breath 10 seconds without rebreathing $=\mathbf{3 0 . 0}$

Rinsing mixture $\mathrm{pO}_{2}=20 \mathrm{~mm}$.

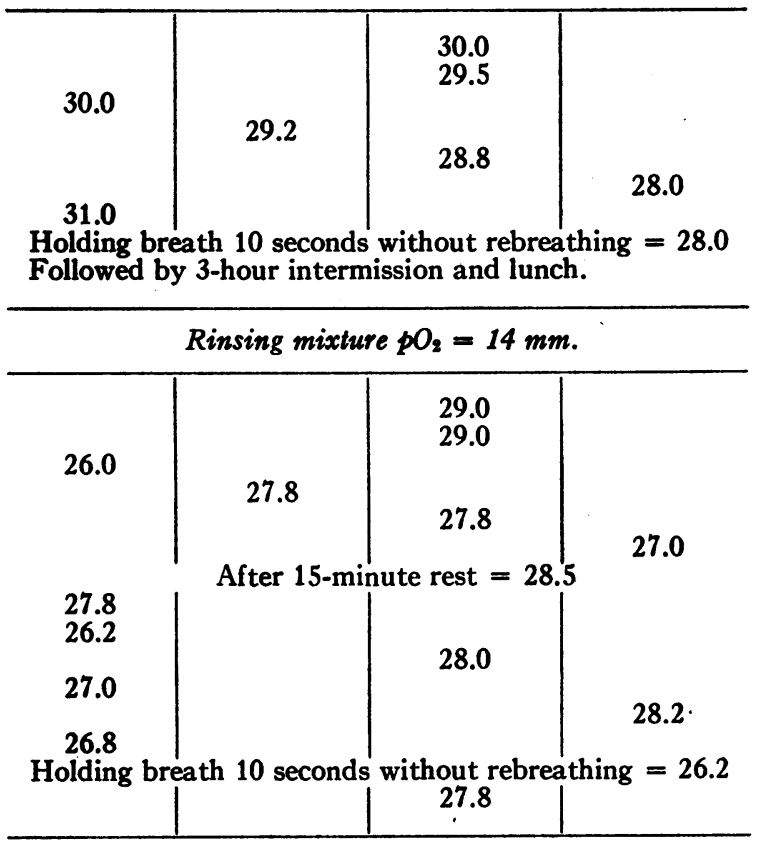

cardio-respiratory abnormalities could be demonstrated by physical examination, $x$-ray of the chest, or electrocardiogram. None had had any previous experience as subjects in respiratory studies. As a rule, fairly consistent data were obtained after one day of practice, with further improvement during the subsequent 3 to 4 days of study. Two additional men were discarded after an unsuccessful trial for one day. The major source of error for most new subjects was admission of outside air to the rebreathed mixture, leading to grossly high values. After this had been eliminated, an appreciable fluctuation of the values persisted in some cases; only 3 or 4 of the subjects appeared capable of maintaining 
as constant a steady state as was demonstrated in Table I by the author. The rinsing mixtures found necessary to produce equilibrium in the various subjects varied from 5 to $25 \mathrm{~mm}$. $\mathrm{pO}_{2}$, but in all cases, the adequacy of equilibration was assured by approaching it from bath the high and the low side.

Table II presents a morning's results from one subject, using the improved procedure of obtaining a rebreathed and an unrebreathed sample from the same rinsing of the lungs. The $\mathrm{MVpO}_{2}$ was quite constant at $27 \mathrm{~mm}$. The values obtained with these subjects on several occasions lay within the narrow range of 26 to $30 \mathrm{~mm}$. at atmospheric pressure and were 2 to 3 $\mathrm{mm}$. lower at a simulated altitude of 12,000 feet.

\section{Discussion}

The major theoretical objection to this method is the possibility of recirculation before equilibrium can be reached. The procedure of 2 rinsings followed by 4 rebreathings occupies a maximal total of 19 seconds. Although the circulation time, measured by tests using the tongue, respiratory center, or appearance of radioactive material as an end-point, is reported to be 12 to 18 seconds in normal subjects (11), this determination omits the distance from the end-point, adjacent to the capillaries, to the level of the venous system at which the test material was injected. This venous path is probably the slowest part of the route, since the cross-section of the system of venules is large in order to function under a very low pressure gradient. In addition, these tests measure the velocity of the most rapid portion of the blood stream, which had taken the shortest route; this may be well ahead of the statistically more significant average speed of recirculation. Evidence was presented above to show that significant recirculation was not present in our experiments, even if the rebreathing were prolonged to 6 breaths. Such a margin of safety is necessary if the method is to be valid under conditions of anoxia, which increases the speed of circulation.

It is felt that the gas mixtures produced by this technic approach. true equilibrium with the venous (pulmonary arterial) blood. The values observed at atmospheric pressure in the author on various days ranged from 29 to $33 \mathrm{~mm}$.
TABLE II

Values of alveolar $\mathrm{pO}_{2}(\mathrm{~mm} . \mathrm{Hg})$ of subject Bernier after rinsing the lungs twice with mixtures of various $\mathrm{O}_{2}$ tensions at atmospheric pressure

\begin{tabular}{c|c|c|c}
\hline Time & $\begin{array}{c}\mathrm{pO}_{2} \text { before } \\
\text { rebreathing }\end{array}$ & $\begin{array}{c}\mathrm{pO}_{2} \text { after 4 } \\
\text { rebreathings }\end{array}$ & $\begin{array}{c}\text { Estimated } \\
\mathrm{MVpO}\end{array}$ \\
\hline
\end{tabular}

Rinsing mixture $\mathrm{pO}_{2}=12.5 \mathrm{~mm}$.

\begin{tabular}{|c|c|c|c|}
\hline $\begin{array}{l}8: 51 \\
8: 54 \\
8: 58 \\
9: 03\end{array}$ & $\begin{array}{l}24.5 \\
22.6 \\
23.0 \\
21.4\end{array}$ & $\begin{array}{l}26.5 \\
26.0 \\
26.5 \\
24.5\end{array}$ & $>26$ \\
\hline \multicolumn{4}{|c|}{ Rinsing mixture $\mathrm{pO}_{2}=22.0 \mathrm{~mm}$. } \\
\hline $\begin{array}{l}9: 10 \\
9: 15 \\
9: 19 \\
9: 23 \\
9: 27 \\
9: 32\end{array}$ & $\begin{array}{l}26.0 \\
26.2 \\
25.5 \\
25.5 \\
25.2 \\
25.2\end{array}$ & $\begin{array}{l}27.0 \\
27.5 \\
26.5 \\
26.5 \\
26.2 \\
26.0\end{array}$ & $>26.5$ \\
\hline \multicolumn{4}{|c|}{ Rinsing mixture $\mathrm{pO}_{2}=24.5 \mathrm{~mm}$. } \\
\hline $\begin{array}{r}9: 41 \\
9: 46 \\
9: 50 \\
9: 56 \\
10: 00\end{array}$ & $\begin{array}{l}27.0 \\
26.2 \\
29.4 \\
27.2 \\
30.2\end{array}$ & $\begin{array}{l}27.4 \\
26.8 \\
27.6 \\
27.0 \\
26.5\end{array}$ & 27.0 \\
\hline \multicolumn{4}{|c|}{ Rinsing mixture $\mathrm{pO}_{2}=31.0 \mathrm{~mm}$. } \\
\hline $\begin{array}{l}10: 18 \\
10: 24 \\
10: 29 \\
10: 35 \\
10: 39 \\
10: 43\end{array}$ & $\begin{array}{l}29.5 \\
30.5 \\
30.0 \\
29.4 \\
32.0 \\
39.5\end{array}$ & $\begin{array}{l}28.8 \\
28.8 \\
31.6 \\
28.4 \\
28.8 \\
32.0\end{array}$ & $<28$ \\
\hline
\end{tabular}

$\mathrm{Hg}-\mathrm{pO}_{2}$. This is lower than most of the results reported by the direct methods, which ranged generally from 35 to $40 \mathrm{~mm}$. This apparent inconsistency may be explained by several considerations: (1) the subject was not basal, the pulse rarely falling below 80 ; (2) the act of rebreathing at a level close to complete expiration involves more muscular effort than normal respiration; (3) the direct measurements, which are the ultimate standard, may be too high because of the accelerated circulation attendant upon the excitement of cardiac puncture; (4) most important, the intermittent exposures to anoxia and acid-base shifts caused by the rebreathing affected the respiratory and circulatory centers, as shown by the fall in alveolar $\mathrm{pO}_{2}$ and $\mathrm{MVpO}_{2}$. Since no studies of blood $\mathrm{pH}$ were made, it is impossible to say whether this change is due to 
respiratory alkalosis induced during the period of hyperpnea upon recovery from the anoxia of the test, or to a direct effect upon the nervous centers. It is to be emphasized that this procedure furnishes reproducible but not basal results.

\section{PART II-EXPERIMENTS AT SIMULATED HIGH ALTITUDE}

\section{Measurement of $\mathrm{MVpO}_{2}$}

Determinations on the author as subject were made with a variety of rinsing mixtures during exposure in a decompression chamber to a simulated altitude of 12,000 feet (U. S. Bureau of Standards-Standard Atmospheric Pressure Table). The results, which are not presented in detail, indicated an even better equilibration at this altitude than at atmospheric pressure. With a series of 6 rinsing mixtures, ranging from 18.5 to $39 \mathrm{~mm} . \mathrm{pO}_{2}$, the $\mathrm{pO}_{2}$ before rebreathing varied from 22 to $32 \mathrm{~mm}$., while the 16 values of $\mathrm{pO}_{2}$ after rebreathing fell within the narrow limits of 24.2 to $27.5 \mathrm{~mm}$. $\mathrm{pO}_{2}$, with an $\mathrm{MVpO}_{2}$ of 25.5 . It was also noted that the "Ordinary Alveolar $\mathrm{pO}_{2}$ " (the last portion of a forcible expulsion following several normal breaths) fell from $\mathbf{5 3 . 5}$ on first reaching this altitude to a steady value of 46 to 48,15 minutes later; during a series of rebreathing experiments, occasional alveolar samples ranged from 37 to $40 \mathrm{~mm}$. It appears that both the early adjustment to altitude and the process of rebreathing affect the respiratory volume, as indicated by the alveolar $\mathrm{pO}_{2}$.

On the basis of this satisfactory equilibration, tests were performed on the same subject at various simulated altitudes using only 1 or 2 gas mixtures at each altitude, since prolonged experiments are difficult under these conditions, and it did not seem indispensable to approach equilibrium from both directions at high altitude. At $16,000,18,000$, and 20,000 feet, the rebreathing caused a brief convulsion, but the subject was able without a single failure to carry out the procedure, taking pure $\mathrm{O}_{2}$ immediately following the final expiration into the bladder. This retreshment was limited to 1 or 2 breaths of $\mathrm{O}_{2}$, since it was desired to interfere as little as possible with the process of acclimatization to the dimin- ished $\mathrm{O}_{2}$ tension. The results are presented in Table III.

\section{Calculation of cardiac compensation}

The values for the Alv. $\mathrm{pO}_{2}$ and $\mathrm{MVPO}_{2}$ at the various altitudes, interpolated from the results in Table III, are assembled in Table IV. From these data, the corresponding percentage saturation of arterial and venous

TABLE III

Alveolar $\mathrm{pO}_{2}$ with appropriate rebreathing mixtures at various simulated altitudes

\begin{tabular}{c|c|c|c|c}
\hline \multirow{3}{*}{ Time } & $\begin{array}{c}\mathrm{pO}_{2} \\
\text { before re- } \\
\text { breathing }\end{array}$ & $\begin{array}{c}\text { after 4 re- } \\
\text { breathings }\end{array}$ & $\begin{array}{c}\text { Ordinary } \\
\text { alveolar } \\
\text { pO2 }\end{array}$ & Conclusion \\
\hline
\end{tabular}

Ground level-atmospheric $\mathrm{pO}_{2} 160$, temp. $72^{\circ} \mathrm{F}$., pulse 88

\begin{tabular}{|c|c|c|c|c|}
\hline 10:00 a.m. & & & $\begin{array}{l}105 \\
100 \\
103\end{array}$ & \\
\hline \multicolumn{5}{|c|}{ Mixture $\mathrm{pO}_{2}=25 \mathrm{~mm}$. } \\
\hline 10:35 a.m. & $\begin{array}{l}34.6 \\
34.0 \\
34.2\end{array}$ & $\begin{array}{l}34.2 \\
32.8 \\
33.0 \\
\\
32.5 \\
32.0\end{array}$ & $\begin{array}{r}92 \\
98 \\
104 \\
\\
95 \\
98 \\
\\
88 \\
89\end{array}$ & $\begin{array}{l}\text { At altitude } 0 \\
\text { Alv. } \mathrm{pO}_{2}=90 \\
\mathrm{MV} \mathrm{pO}_{2}=32.0\end{array}$ \\
\hline
\end{tabular}

Altitude 8,000 feet-atmospheric $\mathrm{pO}_{2} 118$, pulse 88

\begin{tabular}{|c|c|c|c|}
\hline \multicolumn{4}{|c|}{ Mixture $\mathrm{pO}_{2}=27.5 \mathrm{~mm}$. } \\
\hline $\begin{array}{l}30.0 \\
30.0\end{array}$ & $\begin{array}{l}30.5 \\
29.0 \\
29.0\end{array}$ & $\begin{array}{l}\mathbf{6 3 . 0} \\
65.0 \\
\\
\\
56.5 \\
56.5\end{array}$ & \\
\hline \multicolumn{4}{|c|}{ Mixture $\mathrm{pO}_{2}=24.5 \mathrm{~mm}}$. \\
\hline 27.5 & $\begin{array}{r}29.0 \\
28.8 \\
29.2\end{array}$ & $\begin{array}{l}50.5 \\
54.0 \\
58.5 \\
\\
55\end{array}$ & $\begin{array}{l}\text { At } 8,000 \text { feet } \\
\text { Alv. } \mathrm{pO}_{2}=55 \\
\mathrm{MVpO}=29.0\end{array}$ \\
\hline
\end{tabular}


TABLE III-Continued

\begin{tabular}{c|c|c|c|c}
\hline Time & $\begin{array}{c}\mathrm{pO}_{2} \\
\text { before re- } \\
\text { breathing }\end{array}$ & $\begin{array}{c}\mathrm{pO}_{2} \\
\text { after 4 re- } \\
\text { breathings }\end{array}$ & $\begin{array}{c}\text { Ordinary } \\
\text { alveolar } \\
\mathrm{pO}_{2}\end{array}$ & Conclusion \\
\hline
\end{tabular}

Altitude 12,000 feet-atmospheric $\mathrm{pO}_{2}=102$, pulse 90

\begin{tabular}{|c|c|c|c|c|}
\hline \multicolumn{5}{|c|}{ Mixture $\mathrm{pO}_{2}=27.5 \mathrm{~mm}$} \\
\hline $11: 30$ a.m. & $\begin{array}{l}26.0 \\
26.0\end{array}$ & \begin{tabular}{r|}
27.2 \\
25.8 \\
27.8 \\
26.0
\end{tabular} & $\begin{array}{l}48.0 \\
46.0 \\
43.5 \\
\\
42.0 \\
43.2 \\
\\
40.0 \\
39.2 \\
39.5\end{array}$ & $\begin{array}{l}\text { At } 12,000 \text { feet } \\
\text { Alv. } \mathrm{pO}_{2}=40 \\
\mathrm{MVPO}_{2}=26.0\end{array}$ \\
\hline
\end{tabular}

Altitude 16,000 feet-atmospheric $\mathrm{pO}_{2}=86$, pulse 100

Mixture $\mathrm{pO}_{2}=29.5 \mathrm{~mm}$.

\begin{tabular}{|c|c|c|c|c|}
\hline & 25.8 & 24.2 & $\begin{array}{l}36.5 \\
36.5 \\
\\
37.0\end{array}$ & \\
\hline \multicolumn{5}{|c|}{ Mixture $\mathrm{pO}_{2}=25.5 \mathrm{~mm}$. } \\
\hline $12: 15$ p.m. & $\begin{array}{l}24.0 \\
23.5\end{array}$ & $\begin{array}{r}24.0 \\
22.8 \\
23.8 \\
23.2\end{array}$ & $\begin{array}{l}34.0 \\
34.0 \\
33.5\end{array}$ & $\begin{array}{l}\text { At } 16,000 \text { feet } \\
\text { Alv. } \mathrm{pO}_{2}=34.0 \\
\mathrm{MVpO}_{2}=23.5\end{array}$ \\
\hline
\end{tabular}

blood was derived from a standard oxygen dissociation curve, the mean of the 2 similar curves reported for AVB and GSA at $\mathrm{pCO}_{2} 40 \mathrm{~mm}$. (12). The negligible correction for the lower affinity for oxygen of venous as compared with arterial blood was omitted. This difference may be interpolated from the nomogram of the blood of AVB (13) as amounting to less than 1.0 per cent saturation with a change from 35 to $45 \mathrm{~mm}$. $\mathrm{pCO}_{2}$, which exceeds the difference in $\mathrm{pCO}_{2}$ between arterial and venous blood.

It is shown in Table IV that the A-V (arterio-venous) difference (recorded in terms of percentage saturation) falls progressively with increasing altitude. According to the Fick principle, cardiac output equals oxygen consumption divided by $\mathrm{A}-\mathrm{V}$ difference in oxygen content. Since oxygen consumption is essentially unchanged by moderate anoxia (14), the cardiac output is inversely proportional to the $\mathrm{A}-\mathrm{V}$ difference, and the ratio of the cardiac output at any altitude to that at ground level may be simply calculated as the inverse ratio of the respective A-V differences. The cardiac output increases steadily from 106 per cent of normal at 8,000 feet to 189 per cent at 20,000 feet.

The extent to which this increased circulation prevents tissue anoxia may be calculated as follows. If there were no circulatory change ( 0 per cent circulatory compensation), the A-V difference at any altitude would be the same as that at atmospheric pressure, and the venous percentage of saturation at any altitude would be the arterial percentage of saturation minus this fixed A-V difference (34 per cent saturation). Such calculated values are listed in Table IV (Uncompensated venous saturation), in which the following column lists the corresponding oxygen tensions (Uncompensated $\mathrm{MVpO}_{2}$ ), calculated from the

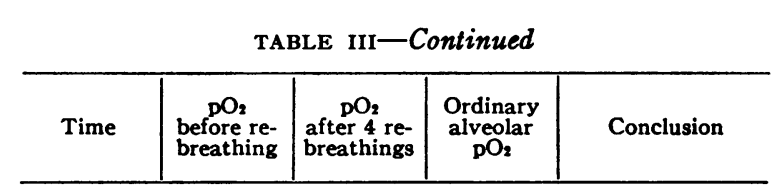

Altitude 18,000 feet-atmospheric $\mathrm{pO}_{2}=80$, pulse 94

\begin{tabular}{|c|c|c|c|c|}
\hline \multicolumn{5}{|c|}{ Mixture $\mathrm{pO}_{2}=24 \mathrm{~mm}$. } \\
\hline $\begin{array}{l}12: 30 \text { p.m. } \\
1: 00 \text { p.m. }\end{array}$ & $\begin{array}{l}22.0 \\
21.8 \\
22.0\end{array}$ & $\begin{array}{l}22.0 \\
22.0 \\
21.8 \\
21.5\end{array}$ & $\begin{array}{l}32.5 \\
30.0 \\
31.0 \\
\\
30.2 \\
30.0\end{array}$ & $\begin{array}{l}\text { At } 18,000 \text { feet } \\
\text { Alv. } \mathrm{pO}_{2}=30.5 \\
\mathrm{MVpO}=21.8\end{array}$ \\
\hline \multicolumn{5}{|c|}{ Altitude 20,000 feet-atmospheric $\mathrm{pO}_{2}=72$, pulse 98} \\
\hline \multicolumn{5}{|c|}{ Mixture $\mathrm{pO}_{2}$ not noted in record } \\
\hline 1:15 p.m. & $\begin{array}{l}21.5 \\
21.0\end{array}$ & $\begin{array}{r}21.5 \\
19.0 \\
19.8 \\
20.0\end{array}$ & $\begin{array}{l}30.0 \\
31.0 \\
\\
28.0 \\
28.0 \\
28.0 \\
28.0\end{array}$ & $\begin{array}{l}\text { At } 20,000 \text { feet } \\
\text { Alv. } \mathrm{pO}_{2}=28.0 \\
\mathrm{MV} \mathrm{pO}_{2}=19.8\end{array}$ \\
\hline
\end{tabular}

Ground level, pulse 82

Mixture $\mathrm{pO}_{2}=22.5 \mathrm{~mm}$.

\begin{tabular}{l|l|l|l|l}
\hline $1: 30$ p.m. & 32.0 & & 78.0 & \\
& & & 82.0 & At altitude 0 \\
& & 31.5 & 76.0 & $\mathrm{MVpO}_{2}=32.0$ \\
& & 32.0 & & \\
\hline
\end{tabular}


TABLE IV

Circulatory data at various altitudes

\begin{tabular}{|c|c|c|c|c|c|c|c|c|c|}
\hline Altitude & $\begin{array}{c}\text { Alveolar } \\
\mathrm{pO}_{2}\end{array}$ & $\begin{array}{l}\mathrm{MV} \\
\mathrm{pO}_{2}\end{array}$ & Arterial & Venous & $\underset{\text { ference }}{A-V \text { dif- }}$ & $\begin{array}{l}\begin{array}{l}\text { Relative } \\
\text { cardiac } \\
\text { output }\end{array} \\
\text { per cent }\end{array}$ & $\begin{array}{c}\begin{array}{c}\text { Uncompensated } \\
\text { venous } \\
\text { saturation }\end{array} \\
\text { per cent }\end{array}$ & $\begin{array}{c}\begin{array}{c}\text { Uncompensated } \\
\mathrm{MVpO}\end{array} \\
m m . \mathrm{Hg} \\
32\end{array}$ & $\begin{array}{c}\begin{array}{c}\text { Circulatory } \\
\text { compensation }\end{array} \\
\text { per cent }\end{array}$ \\
\hline $\begin{array}{c}0 \\
8,000 \\
12,000 \\
16,000 \\
18,000 \\
20,000\end{array}$ & $\begin{array}{c}80 \text { to } 90 \\
55 \\
40 \\
34.0 \\
30.5 \\
28.0\end{array}$ & $\begin{array}{l}32.0 \\
29.0 \\
26.0 \\
23.5 \\
21.8 \\
19.8\end{array}$ & $\begin{array}{l}97 \\
89 \\
77 \\
67 \\
61 \\
55\end{array}$ & $\begin{array}{l}63 \\
57 \\
51 \\
45 \\
42 \\
37\end{array}$ & $\begin{array}{l}34 \\
32 \\
26 \\
22 \\
19 \\
18\end{array}$ & $\begin{array}{l}100 \\
106 \\
130 \\
155 \\
179 \\
189\end{array}$ & $\begin{array}{l}63 \\
55 \\
43 \\
33 \\
27 \\
21\end{array}$ & $\begin{array}{l}32 \\
28 \\
22.5 \\
18 \\
15.5 \\
13.5\end{array}$ & $\begin{array}{l}25 \\
40 \\
40 \\
42 \\
38\end{array}$ \\
\hline
\end{tabular}

Alveolar $\mathrm{pO}_{2}$ and $\mathrm{MVpO}_{2}$ were determined at the various altitudes and the other data calculated from them. Uncompensated Venous Saturation and $\mathrm{MVpO}_{2}$ represent the values which these functions would have had if the A-V difference had remained constant and the Alveolar $\mathrm{pO}_{2}$ had varied as observed at each altitude.

standard dissociation curve. If, on the other hand, there were 100 per cent circulatory compensation, the venous percentage of saturation would remain constant at its normal value at atmospheric pressure (63 per cent) and the A-V difference would drop proportionately with decreasing arterial saturation. Actually, the venous percentage of saturation lies between the 2 extremes, and the extent of circulatory compensation may be calculated by the formula:

Percentage of circulatory compensation $=100$

Actual venous percentage of saturation - Uncompensated venous percentage of saturation

$$
\times
$$

Normal venous percentage of saturation

-Uncompensated venous percentage of saturation

For example, at 12,000 feet the Venous percentage of saturation was 51 , and the Uncompensated venous percentage of saturation would be $77-34=43$; the normal venous percentage of saturation was 63 ; the percentage of circulatory compensation was therefore $100 \times \frac{51-43}{63-43}$ $=\mathbf{4 0}$ per cent. At all altitudes but the lowest, the calculated circulatory compensotion was about $\mathbf{4 0}$ per centi.e., the lowering of venous percentage of saturation was $2 / 5$ less than it would have been if the cardiac output were constant. The lower value ( 25 per cent) at 8,000 feet is not very significant, since the slight anoxia here caused so small a deviation of $\mathrm{MVpO}_{2}$ from normal that the calculation of circulatory compensation was subject to a large error.

The circulatory compensation may also be evaluated by a similar formula applied to $\mathrm{O}_{2}$ tensions rather than to saturations, with similar results. Translated into terms of an aviator's "ceiling," $\mathrm{MVpO}_{2}$, and hence the tissue oxygen tension, at an altitude of 18,000 feet is that which would have been reached at 13,000 feet if there were no circulatory compensation.

The data of Table IV are also presented in Figure 1, in which the shaded areas indicate the extent to which circulatory compensation decreases anoxia.

\section{Discussion}

The calculation of cardiac compensation rests on the assumption that the gas in the alveoli is in equilibrium with the blood leaving the alveolar capillaries. On the basis of the evidence of equilibrium shown in Part $I$, this assumption seems justifiable for the equilibrium between $\mathrm{MVpO}_{2}$ and venous blood. The question of the equilibrium between ordinary alveolar air and arterial blood, however, has long been debated, with general abandonment of the secretion theory. The more acceptable diffusion theory presupposes the existence of a gradient, however small, and therefore a higher value for alveolar than arterial $\mathrm{pO}_{2}$. Dill, Christensen, and Edwards (15), on the Chilean expedition, found an average alveolar-arterial difference at an altitude of $4.7 \mathrm{~km}$. of only about $2 \mathrm{~mm}$., but Dill, Edwards, and Robinson (16) noted somewhat larger differences in subjects breathing nitrogen-oxygen mixtures or subjects in a chamber decompressed to an oxygen tension of $86 \mathrm{~mm}$. Since we have not determined arterial saturation directly, we must assume that equilibrium exists. ${ }^{1}$ It is likely that the error so introduced is small and

\footnotetext{
1 Recent work by F. J. W. Roughton (personal communication) has indicated that the difference observed between measured arterial saturation and that predicted from alveolar $\mathrm{pO}_{2}$ may be largely due to an artefact, caused by the presence in normal blood of appreciable quantities of methemoglobin. This appears to be rapidly reduced after the blood is drawn and thereby to increase the measured oxygen capacity and hence decrease the apparent saturation. It may be that the alveolar $\mathrm{pO}_{2}$ is actually a better measure of arterial saturation than is the usual measurement of content divided by capacity.
} 


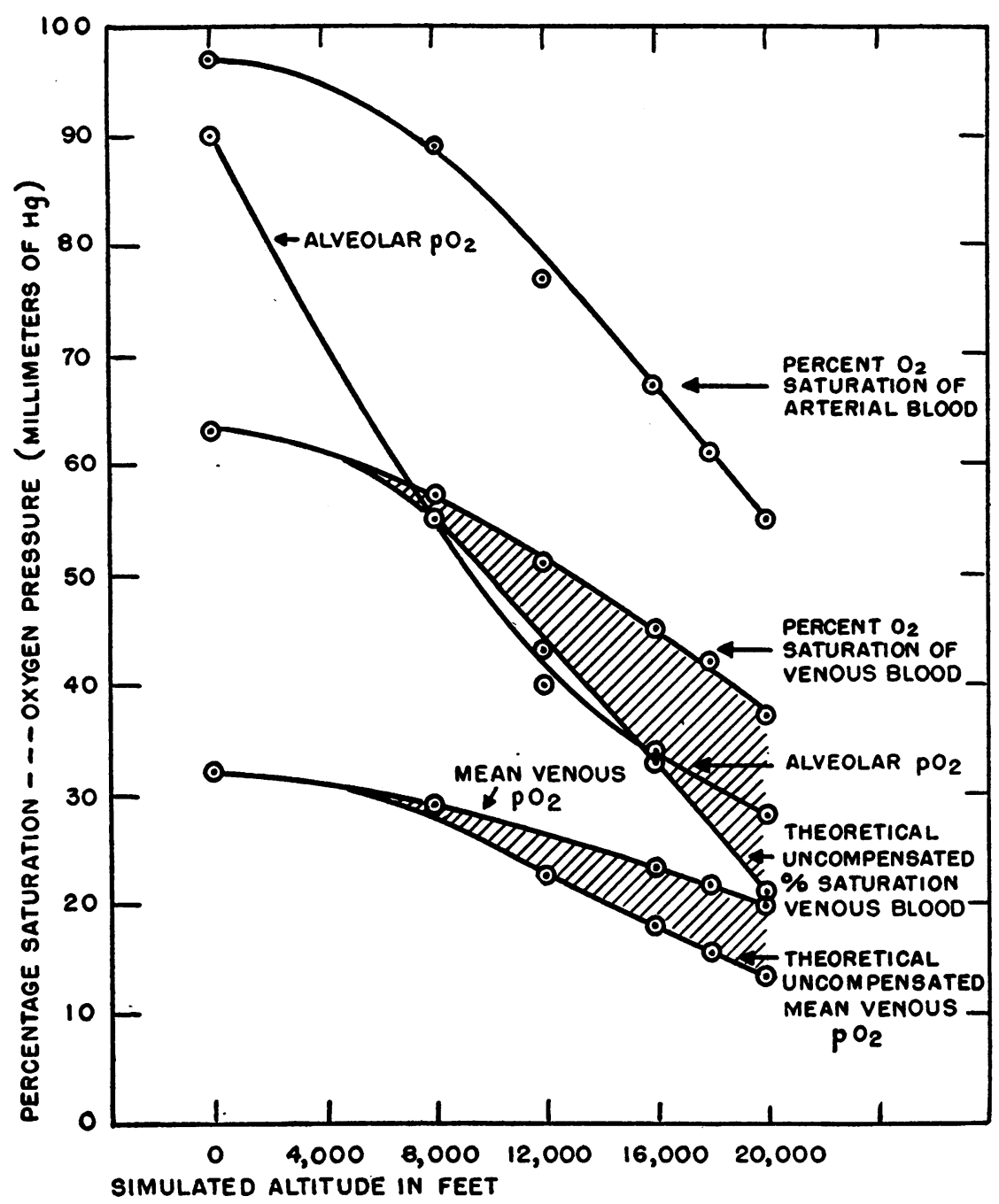

Fig. 1. Circulatory Data on Subject BDD at Various Simulated Altitudes in Decompression Chamber

Alveolar $\mathrm{pO}_{2}$ and $\mathrm{MV}_{2} \mathrm{O}_{2}$ were determined and the other data calculated from them. The shaded areas represent the effectiveness of the increased cardiac output in diminishing tissue anoxia.

fairly constant in terms of percentage of saturation at various altitudes.

Another source of error in this calculation is the utilization of a standard oxygen dissociation curve. The largest deviations in the various reported curves occur in the lower portion, which corresponds to the values of $\mathrm{MVpO}_{2}$ at high altitudes. If we choose 1 of the 2 curves of Bock, Field, and Adair (12), rather than the mean of the 2 curves as was done, the circulatory compensation values at the various altitudes are in the neighborhood of 33 per cent rather than 40 per cent. While the accuracy of the calculations is undoubtedly limited by these assumptions regarding alveolar-arterial equilibrium and the applicability of an $\mathrm{O}_{2}$ dissociation curve obtained on another individual, it is felt that the order of magnitude of the calculated cardiac compensation, and its relative constancy at various altitudes, are valid derivations from the data. It may be noted that Grollman (14), measuring cardiac output by the acetylene method while 
breathing air $-\mathrm{N}_{2}$ mixtures, detected no decrease in $\mathrm{A}-\mathrm{V}$ difference until the mixtures reached a $\mathrm{pO}_{2}$ as low as $87 \mathrm{~mm}$. (corresponding to $c a$. 16,000 feet).

The increases in cardiac output calculated above are well above the observed increases in pulse rate (10 to 20 per cent at 16 to 20,000 feet), indicating an effect of anoxia on stroke volume as well as on heart rate. Such an effect has been reported by Herbst and Manigold (17), who by an indirect sphygmographic method found an increase of stroke volume of 15 to 45 per cent and an increase of minute volume of 30 to 70 per cent in a number of subjects at simulated altitudes of 5 to $8,000 \mathrm{~m}$. Matthes and Malikiosis (18) measured arterial saturation by a photoelectric colorimetric method across the ear lobe, and venous saturation by the same method after holding the lungs full of nitrogen until venous blood reached the ear capillaries. At a simulated altitude of $6,000 \mathrm{~m}$., they found a doubling of minute volume, a 75 per cent increase in stroke volume, and a decrease of venous saturation to 54 to 61 per cent, from 68 to 72 per cent observed at atmospheric pressure. In contrast with these results, Keys et al. (19), using the less indirect technic of roentgenkymography, reported little or no increase in stroke volume with gas mixtures corresponding to an altitude of 18,000 to 28,000 feet.

It is to be emphasized that the indirect method of measuring $\mathrm{MVpO}_{2}$ here presented involves considerable departure from the basal states but there appear to be no systematic errors to invalidate the comparison of values obtained at various altitudes or in different individuals. In 7 of 8 subjects, a correlation was noted between the $\mathrm{MVpO}_{2}$ at 12,000 feet and resistance to loss of consciousness at higher altitudes. The values obtained with these and other normal individuals, however, fell within so narrow a range that it appears unlikely that very significant differences between subjects can be established.

\section{SUMMARY}

A method is presented for determining the mean venous oxygen tension $\left(\mathrm{MVpO}_{2}\right)$ indirectly by means of equilibrating gas mixture of low $\mathrm{pO}_{2}$ with pulmonary arterial blood. Reproducible results were produced under standard but non- basal conditions, ranging in 15 individuals from 26 to $32 \mathrm{~mm}$. $\mathrm{Hg}$ at atmospheric pressure.

Observations at simulated altitudes of 8,000 to 20,000 feet indicated that the cardiac output rose progressively with altitude, reaching 189 per cent of normal at 20,000 feet. This circulatory compensation decreased the tissue anoxia at the various altitudes by 40 per cent, the $\mathrm{MVpO}_{2}$ at 20,000 feet being $19.8 \mathrm{~mm}$. rather than the value of $13.5 \mathrm{~mm}$. which would have obtained if the cardiac output were constant.

\section{BIBLIOGRAPHY}

1. Baumann, H., and Grollman, A., Über die theoretischen und praktischen Grundlagen und die klinische Zuverlässigkeit der Acetylenmethode zur Bestimmung des Minutenvolumens. Ztschr. f. klin. Med., 1930, $115,41$.

2. Klein, O., Zur Bestimmung des zirkulatorischen Minutenvolumens beim Menschen nach dem Fickschen Prinzip. München. med. Wchnschr., 1930, 77, 1311.

3. Plesch, J., Hämodynamische Studien. Ztschr. f. exp. Path. u. Therap., 1909, 6, 380.

4. Fridericia, L. S., Untersuchungen an Menschen über Sauerstoff und Kohlensäurespannung im Blut der Pulmonalarterie und über Messung des Minutenvolumens des Herzens. Biochem. Ztschr., 1918, 85, 307.

5. Barcroft, J., Roughton, F. J. W., and Shoji, R., The measurement of the oxygen content of the mixed venous blood, and of the volume of blood circulating per minute. J. Physiol., 1921, 55, 371.

6. Redfield, A. C., Bock, A. V., and Meakins, J. C., The measurement of the tension of oxygen and carbon dioxide in the blood of the pulmonary artery in man. J. Physiol., 1922, 57, 76.

7. Burwell, C. S., and Robinson, G. C., A method for the determination of the amount of oxygen and carbon dioxide in the mixed venous blood of man. J. Clin. Invest., 1924, 1, 47.

8. Murray, C. D., and Taylor, H., A method for the determination of the oxygen and carbon dioxide tensions in mixed venous blood. J. Physiol., 1925, 59, Ixvii.

9. Richards, D. W., Jr., and Strauss, M. L., Carbon dioxide and oxygen tensions of the mixed venous blood of man at rest. J. Clin. Invest., 1930, 9, 475.

10. Grollman, A., The Cardiac Output of Man in Health and Disease. C. C. Thomas, Springfield, 1932.

11. Blumgart, H. L., The velocity of blood flow in health and disease. Medicine, 1931, 10, 1.

12. Bock, A. V., Field, H., Jr., and Adair, G. S., The oxygen and carbon dioxide dissociation curves of human blood. J. Biol. Chem., 1924, 59, 353.

13. Bock, A. V., Dill, D. B., Hurxthal, L. M., Lawrence, 
J. S., Coolidge, T. C., Dailey, M. E., and Henderson, L. J., Blood as a physicochemical system. V. The composition and respiratory exchanges of normal human blood during work. J. Biol. Chem., $1927,73,749$.

14. Grollman, A., Physiological variations of the cardiac output of man. VII. The effect of high altitude on the cardiac output and its related functions. Am. J. Physiol., 1930, 93, 19.

15. Dill, D. B., Christensen, E. H., and Edwards, H. T., Gas equilibria in the lungs at high altitudes. Am. J. Physiol., 1936, 115, 530.

16. Dill, D. B., Edwards, H. T., and Robinson, S., Pul- monary gaseous exchanges at low barometric pressure and in air mixed with nitrogen. J. Aviation Med., 1939, 10, 3.

17. Herbst, R., and Manigold, K., Das Verhalten von Kreislauf und Atmung bei Sauerstoffmangel. Arbeitsphysiol., 1936, 9, 166.

18. Matthes, K., and Malikiosis, X., Über das Verhalten von Kreislauf und Atmung im Unterdruck. Luftfahrtmed., 1937, 1, 259.

19. Keys, A., Stapp, J. P., and Violante, A., Responses in size, output, and efficiency of the human heart to acute alteration in the composition of inspired air. Am. J. Physiol., 1943, 138, 763. 